\title{
Методологічні основи управління оборонними ресурсами в Збройних силах України
}

\author{
Олег Семененко * 1 А; Петро Онофрійчук 2 А; Ірина Чернишова ${ }^{3}$ А; \\ Олег Остапець ${ }^{4}$ в; Іван Мотрунич 5 в; Ольга Романченко 6 с \\ А Центральний науково-дослідний інститут Збройних Сил України, м. Київ, Україна

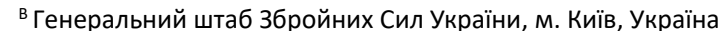 \\ с Національний університет оборони України імені Івана Черняховського, м. Київ, Україна
}

Received: October 7, 2021 | Revised: October 18, 2021 | Accepted: October 30, 2021

DOI: $10.33445 /$ sds.2021.11.5.10

\begin{abstract}
Анотація
В існуючих умовах розвитку держави, коли системи оборонного планування України адаптується до стандартів НАТО, розвиток Збройних Сил (3С) України повинен базуватися на показниках необхідного рівня обороноздатності країни з урахуванням її економічних можливостей щодо забезпечення потреб в оборонних ресурсах. Для України питання оборонного менеджменту, оборонного планування, який грунтується на принципах програмно цільового управління та управління оборонними ресурсами $\epsilon$ недостатньо вивченим. Керівництво ЗС України та держави в цілому бажає найшвидше перейти до оборонного планування за стандартами НАТО, а саме із застосуванням методу “планування на основі спроможностей". Проте нині в Україні відсутні методологічні основи управління оборонними ресурсами, що має негативні наслідки. Аналіз сучасних досліджень засвідчує, що сьогодні активно використовується термін управління оборонними ресурсами проте, в літературі зустрічається безліч його неоднозначних тлумачень. Крім того, важко знайти єдиний підхід до управління оборонними ресурсам. Тому необхідним та актуальним завданням $€$ дати визначення терміну "управління ресурсами» та окреслити методологічні основи управління оборонними ресурсами в ЗС України. Сформовані методологічні основи повинні дати відповіді на питання щодо переліку, змісту та алгоритму реалізації методів управління оборонними ресурсами, а також розкрити питання практичної значимості процесу управління оборонними ресурсами. Пропоновані методологічні основи управління оборонними ресурсами за своєю сутністю $€$ сукупність уточненого (стандартного для усіх рівнів 3С України) понятійнотермінологічного апарату, розробленої концепції подальшого розвитку системи управління оборонними ресурсами та методичного апарату воєнно-економічного обґрунтування розвитку ЗС України, який являє собою набір методів, прийомів, способів дослідження питань управління оборонними ресурсами.

Подальші дослідження можуть бути пов'язані з розробленням практичних рекомендацій щодо створення та розвитку в ЗС України окремої ланки управління, яка відповідає безпосередньо за управління оборонними ресурсами.
\end{abstract}

Ключові слова: ресурси, забезпечення, витрати, менеджмент, ефективність.

\section{Постановка проблеми}

В існуючих умовах розвитку держави, коли системи оборонного планування України адаптується до стандартів НАТО, розвиток
Збройних Сил (ЗС) України повинен базуватися на показниках необхідного рівня обороноздатності країни з урахуванням ії

\footnotetext{
1 * Corresponding author: доктор військових наук, професор, начальник відділу, e-mail: aosemenenko@ukr.net, ORCID: 0000-0001-6477-3414

2 кандидат економічних наук, старший науковий співробітник, e-mail: aosemenenko@ukr.net, ORCID: 0000-0003-2203-5282

${ }^{3}$ кандидат військових наук, старший науковий співробітник, e-mail: aosemenenko@ukr.net, ORCID: 0000-0002-5958-7059

${ }^{4}$ кандидат військових наук, e-mail: aosemenenko@ukr.net, ORCID: 0000-0002-4702-980X

5 здобувач, e-mail: aosemenenko@ukr.net, ORCID: 0000-0001-6117-1784

6 здобувач наукового ступеня, e-mail: alena.rondo@gmail.com, ORCID: 0000-0003-1640-853X
} 
економічних можливостей щодо забезпечення потреб в оборонних ресурсах. Для України питання оборонного менеджменту, оборонного планування на принципах програмно цільового управління та управління оборонними ресурсами $€$ недостатньо вивченим. Останнім часом відбувається багато перетворень та трансформацій в ЗС України, зокрема в 2020 році в Генеральному штабі $3 С$ України відбулися організаційно-штатні зміни, у зв'язку з чим створено Центральне управління оборонними ресурсами [1].
Створення окремої ланки управління, яка відповідає безпосередньо за управління оборонними ресурсами ії подальший розвиток та становлення повинно бути науковообґрунтованим та виваженим. Усе це свідчить про необхідність удосконалення існуючих підходів до формування потреб зС України та забезпечення їх різними видами ресурсів. Тому визначення методологічних основ управління оборонними ресурсами в ЗС України $\epsilon$ необхідним на актуальним завданням сьогодення.

\section{Аналіз останніх досліджень та публікацій}

Боєздатність збройних сил будь-якої держави напряму залежить від їх забезпечення оборонними ресурсами, про що написано в багатьох публікаціях [1-15]. Аналіз сучасних досліджень засвідчує, що сьогодні активно використовується термін управління оборонними ресурсами проте, в літературі зустрічається безліч його неоднозначних тлумачень. Крім того, важко знайти єдиний підхід до управління оборонними ресурсам.

\section{Постановка завдання}

Тому необхідним та актуальним завданням $\epsilon$ дати визначення терміну "управління ресурсами" та окреслити основи управління оборонними ресурсами В ЗС

\author{
України. Метою статті $€$ представити \\ методологічні основи управління \\ оборонними ресурсами в ЗС України.
}

\section{Виклад основного матеріалу}

Під поняттям, управління ресурсами, на думку авторів, слід розуміти процес, в рамках якого розпорядники ресурсів ефективно управляють різноманітними ресурсами, наявними в їх розпорядженні. Ці ресурси можуть бути нематеріальними (люди, час) i матеріальними (обладнання, матеріали, фінанси). Схематична класифікація ресурсів у розрізі поняття управління ресурсами в Збройних Силах України представлена на рис. 1.

На найпростішому рівні управління ресурсами означає вжитя заходів для найбільш ефективного та розумного використання різних видів ресурсів суб'єктом, що їх має у розпорядженні.

Управління фінансовими ресурсами повинно дати відповіді на такі запитання: Чи достатньо коштів для покриття поточних витрат (утримання, підготовка)? Чи можна дозволити собі інвестиції в нове озброєння, обладнання або навчання особового складу?

Управління людськими ресурсами повинно дати відповіді на запитання про достатність особового складу (ОС) для виконання визначених завдань зС України в певний час або період. Чи знадобиться наймати когось ще, і якщо так, то якими навичками повинні будуть вони володіти?

Управління матеріальними ресурсами повинно дати відповіді на такі питання: Чи дозволяє розташування військових формувань управляти іншими ресурсами з максимальною ефективністю? Чи є в розпорядженні ЗС України озброєння, техніка, обладнання тощо, необхідні для виконання поставлених їм завдань? 

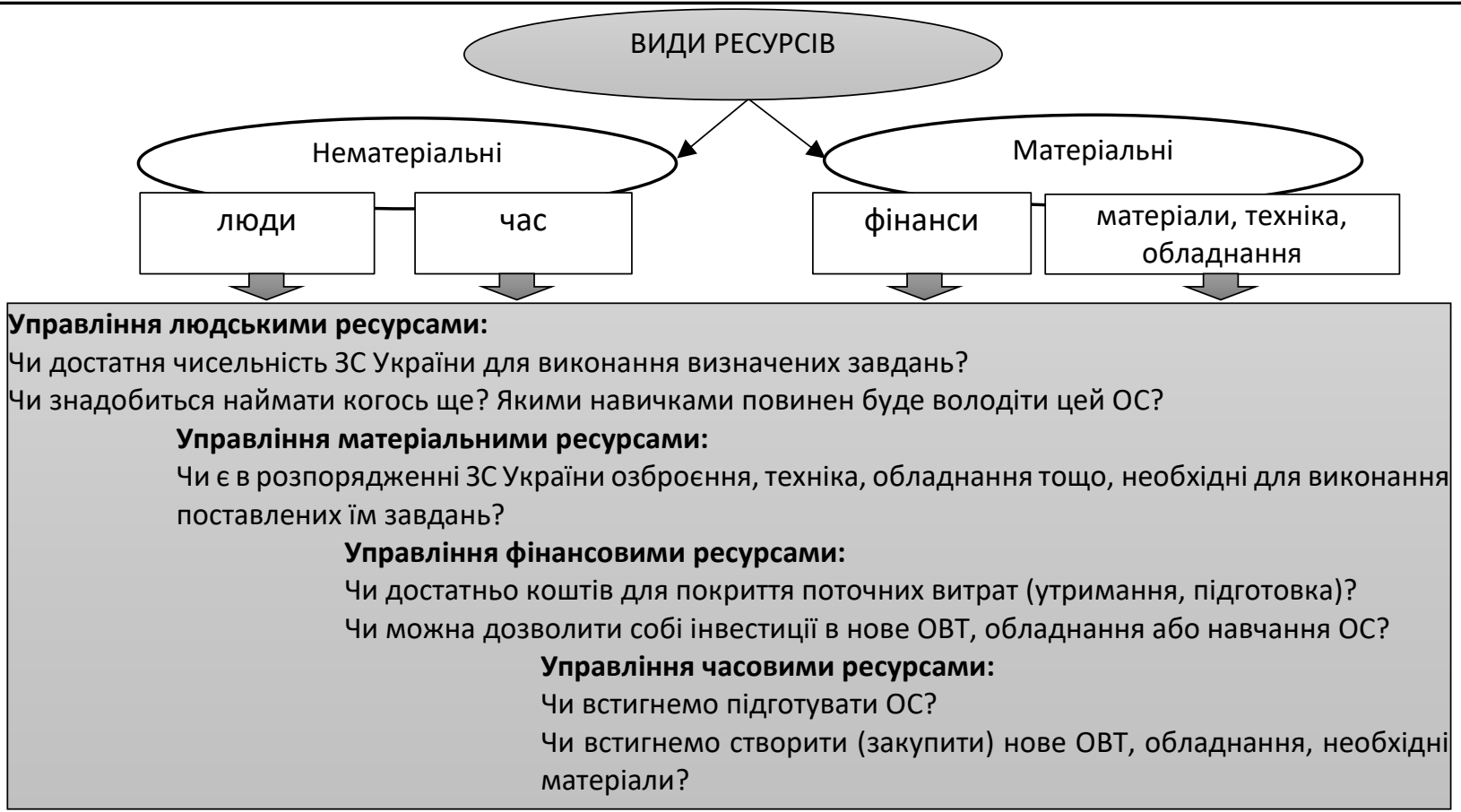

Рисунок 1 - Класифікація ресурсів у розрізі поняття управління ресурсами в Збройних Силах України

Що необхідно ЗС України для досягнення успіху, і чи $\epsilon$ потреба в перерозподілі фінансових ресурсів таким чином, щоб придбати відсутні нематеріальні ресурси? Управління часовими ресурсами повинно дати відповіді на запитання про своєчасність постачання тих чи інших ресурсів. Чи встигнемо підготувати ОС? Чи встигнемо створити (закупити) нове ОВТ, обладнання, необхідні матеріали?

Аналіз наведених запитань та очікуваних відповідей на них дає можливість уточнити визначення терміну "Управління ресурсами". Отже, можна стверджувати, що "управління ресурсами" - це процес завчасного планування ресурсів (формування бюджетів та часових графіків) та розподілу наявних ресурсів, а також розподілу ролей між учасниками процесу розвитку системи (розпорядниками ресурсів) для вирішення конкретних завдань та досягнення найкращого результату поставленої цілі у визначений час.

Планування ресурсів $\epsilon$ одним із обов'язкових атрибутів будь-якого управління ресурсами. Основними методами планування ресурсів у загальному процесі управління ними $\epsilon$ методи вирівнювання та згладжування ресурсів. На рис. 2 зображено основні методи планування ресурсів.

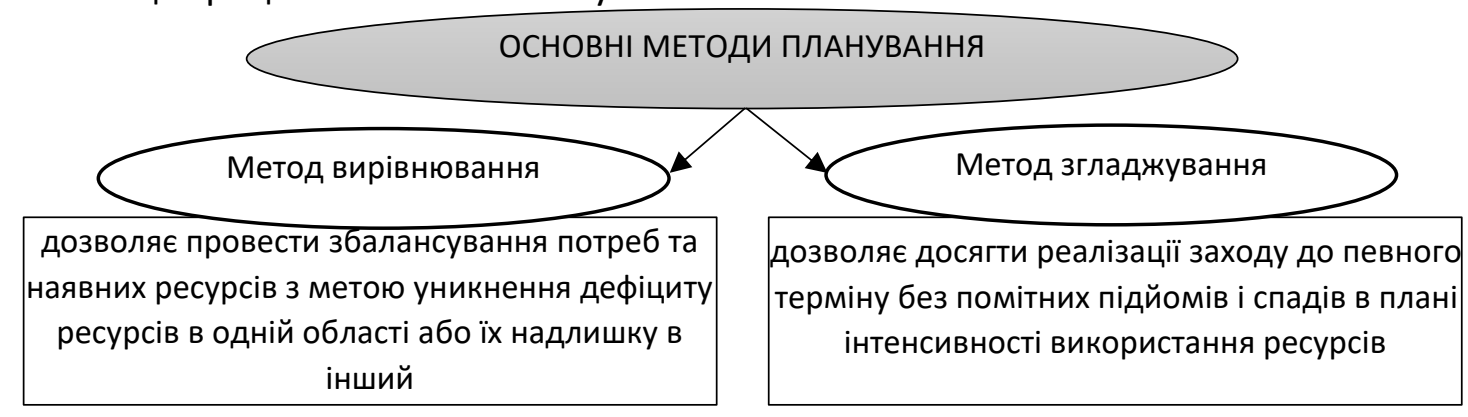

Рисунок 2 - Основні методи планування ресурсів у загальному процесі управління ними

Вирівнювання ресурсів це метод планування ресурсів, що дозволяє провести 
збалансування потреб та наявних ресурсів 3 метою уникнення дефіциту ресурсів в одній області або їх надлишку в інший. Вирівнювання ресурсів взаємопов'язане із часовим ресурсом, де дата початку та закінчення заходу програми (плану) коригується таким чином, щоб обидві дати збігалися $з$ наявністю відповідних ресурсів. Вирівнювання може збільшити термін реалізації заходу.

Згладжування ресурсів - це метод планування, що дозволяє досягти реалізації заходу до певного терміну без помітних підйомів і спадів в плані інтенсивності використання ресурсів. Мета згладжування ресурсів рівномірне використання ресурсів в динаміці за часом.

Термін управління оборонними ресурсами запозичений з англійської мови від поняття "defense resource management", сьогодні достатньо часто асоціюється із поняттям оборонного менеджменту, який передбачає процес менеджменту, що здійснюється на всіх рівнях організації і регулює весь спектр організаційної діяльності.

Оборонний менеджмент, розглянутий в рамках більш широкої сфери національної політики в галузі оборони і безпеки, $є$ процес, який включає в себе, в першу чергу, державні органи, що відповідають за розробку цієї політики i визначення бюджету оборони i безпеки. Роль парламентів у нагляді за цим процесом планування має особливе значення. Другий етап оборонного менеджменту, пов'язаний з фактичним здійсненням політики та управлінням ресурсами (організація, забезпечення кадрами, фінансами), здійснюється військовим і цивільним персоналом оборонного сектора. Заключний етап циклу оборонного менеджменту моніторинг і контроль-включає в себе широке коло учасників, таких як парламентарії, інститути омбудсменів, аудитори, інспектори, громадянське суспільство і засоби масової інформації. Їх завдання - стежити за процесом, 3 метою дотримання національних i міжнародних стандартів ефективного управління, а також для запобігання корупційних дій та забезпечення зворотного зв'язку для його поліпшення. Схематично основні етапи оборонного менеджменту можна представити у вигляді рис. 3.

\begin{tabular}{|l|l|l|}
\hline $\begin{array}{l}\text { 1. Державні органи, що } \\
\text { відповідають за розробку } \\
\text { національної політики в галузі } \\
\text { оборони та безпеки, а також } \\
\text { визначення бюджету оборони і } \\
\text { безпеки } \\
\text { 2. Парламент здійснює нагляд } \\
\text { за процесом оборонного } \\
\text { менеджменту }\end{array}$ \\
$\begin{array}{l}\text { 1. Фактичне здійснення } \\
\text { національної політики в галузі } \\
\text { оборони та безпеки } \\
\text { 2. Управлінням оборонними } \\
\text { ресурсами (організація, } \\
\text { забезпечення), здійснюється } \\
\text { військовим і цивільним } \\
\text { персоналом оборонного } \\
\text { сектору }\end{array}$
\end{tabular}

Рисунок 3 - Основні етапи оборонного менеджменту

Воєнно-політична обстановка навколо країни формує перелік можливих викликів та загроз державі у воєнній сфері, за результатами оцінювання яких формуються імовірні сценарії виникнення та розвитку ситуацій щодо переліку сформованих загроз. Оцінки ймовірності виникнення різних сценаріїв $\in$ основою формування довгострокових, середньострокових та короткострокових програм та планів розвитку 
3С України. Але наявність ресурсної обмеженості держави, яка викликана ії економічними можливостями, створює передумови до пошуку компромісних рішень щодо величини рівня здатності ЗС України вирішувати увесь перелік поставлених ним завдань та напруженістю економіки держави щодо забезпечення цього рівня. Такий стан справ і формує необхідність процесу ефективного управління ресурсами.

Сьогодні в умовах трансформації системи оборонного планування до стандартів НАТО, виникає ряд проблемних питань, які обумовлені існуючою проблематикою узгодженості бюджетного та оборонного планування. Основними проблемами узгодженості бюджетного та оборонного планування в рамках управління оборонними ресурсами $\epsilon$ значні розбіжності між показниками потреб ЗС України та виділеними державою фінансовими ресурсами (понад 20\%), що, в свою чергу, призводить до нераціонального розподілу виділених державою фінансових ресурсів (де 70-80\% займають заходи утримання), що негативно позначається на ефективності виконання програм розвитку ЗС України.

Керівництво ЗС України та держави в цілому бажає найшвидше перейти до оборонного планування за стандартами HATO, а саме із застосуванням методу “планування на основі спроможностей". Проте нині в Україні відсутні методологічні основи управління оборонними ресурсами, що має негативні наслідки. Отже, пропоновані методологічні основи управління оборонними ресурсами за своєю сутністю $€$ сукупність уточненого (стандартного для усіх рівнів 3С України) понятійно-термінологічного апарату, розробленої концепції подальшого розвитку системи управління оборонними ресурсами та методичного апарату воєнноекономічного обґрунтування розвитку ЗС України, який являє собою набір методів, прийомів, способів дослідження питань управління оборонними ресурсами.
Сформовані методологічні основи повинні дати відповіді на питання щодо переліку, змісту та алгоритму реалізації методів управління оборонними ресурсами, а також розкрити питання практичної значимості процесу управління оборонними ресурсами. Сьогодні Центральне управління оборонними ресурсами ГШ ЗС України сумісно із Центральним науково-дослідним інститутом 3С України було вже зроблено спробу щодо формування основних методологічних положень процесу управління оборонними ресурсами В ЗС України, які були втілені у розроблених Доктринах щодо управління обробними ресурсами та організації управління оборонними ресурсами.

Розроблені доктрини управління оборонними ресурсами призначені для визначення основ планування оборонних ресурсів, управління ними та основних положень організації цих процесів. Розроблені Доктрини передбачені для використання В органах військового управління, у військах (силах), військових частинах та установах, вищих військових навчальних закладах, військово-навчальних підрозділах закладів вищої освіти та в навчальних центрах ЗС України.

Сьогодні адаптація системи оборонного планування до сучасних умов розвитку держави, а також розвиток та реформування ЗС України повинні базуватися на показниках необхідного рівня обороноздатності країни 3 урахуванням економічних можливостей держави щодо забезпечення потреб в оборонних ресурсах.

Умовно місце методології управління оборонними ресурсами у загальній системі методології управління розвитком країни в цілому, можна представити як на мал. 4.

Наведена ієрархія показує місце методології управління оборонними ресурсами у загальній системі методологічних досліджень та ії взаємозв'язок із іншими методологіями. 


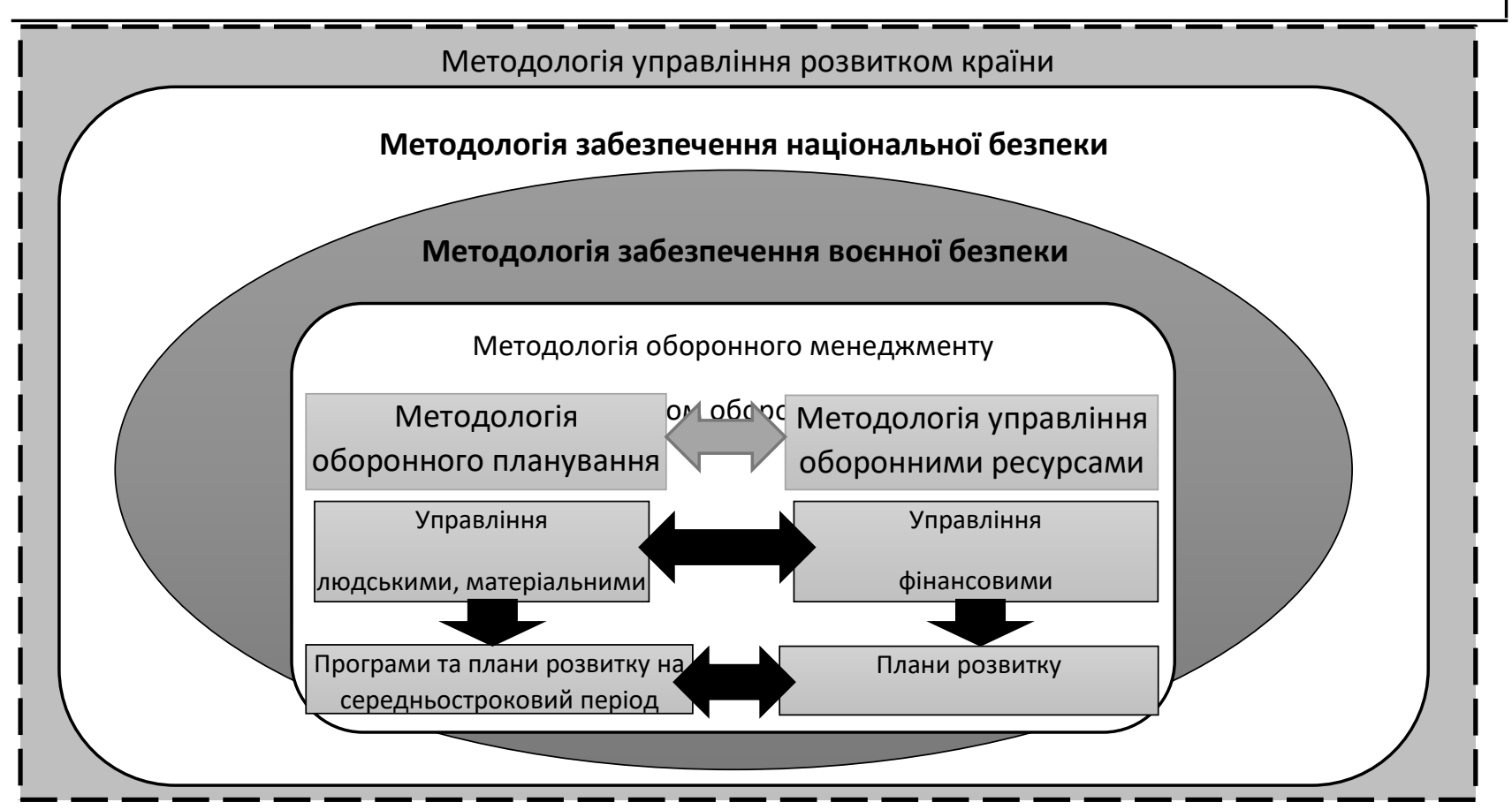

Рисунок 4 - Місце методології управління оборонними ресурсами у загальній системі методології управління розвитком країни

Методологія забезпечення національної безпеки $\epsilon$ складовою загальної системи методологічних досліджень управління країною в цілому, а методологія воєнної безпеки є відповідно ії складовою.

У свою чергу, за визначеною ієрархією, основою методологічних досліджень щодо забезпечення необхідного рівня воєнної безпеки країни $€$ методологічні дослідження питань оборонного менеджменту, тобто управління розвитком оборонної сфери держави. Основою яких $\epsilon$ методологічні дослідження за двома взаємопов'язаними методологічними напрямами, а саме методологія оборонного планування та методологія управління оборонними ресурсами. Методологія оборонного планування у своїй більшості досліджує питання управління людськими, матеріальними, часовими ресурсами та тільки частково фінансовими ресурсами під час формування програм та планів середньострокового періоду, а безпосередньо методологія управління оборонними ресурсами, досліджує питання управління фінансовими ресурсами під час формування планів короткострокового періоду, а й відповідно через зворотний зв'язок людськими, матеріальними та часовими ресурсами. Тому ці обидва напрями методологічних досліджень поєднані одним цілим, та більш ширшим за обсягами методологічними дослідженнями питань оборонного менеджменту.

В умовах постійної динаміки стану розвитку національної економіки держави та впливу низки зовнішніх та внутрішніх факторів на розвиток ЗС України, забезпе-чення потреб їх розвитку в ресурсах повинно бути побудовано за принципами ефектив-ного використання та управління оборон-ними ресурсами, як на стадії формування документів оборонного планування, так і під час їх безпосереднього виконання. Але забезпечення ефективного управління оборонними ресурсами можливо тільки за умов завчасного передбачення (прогнозу-вання) та достовірного урахування впливів різних факторів як на сам процес управління оборонними ресурсами, так і на процес розвитку ЗС України в цілому.

До основних факторів, які визначальним чином впливають на ефективність управління оборонними ресурсами на рівні ЗС України $€$ (рис. 5): 


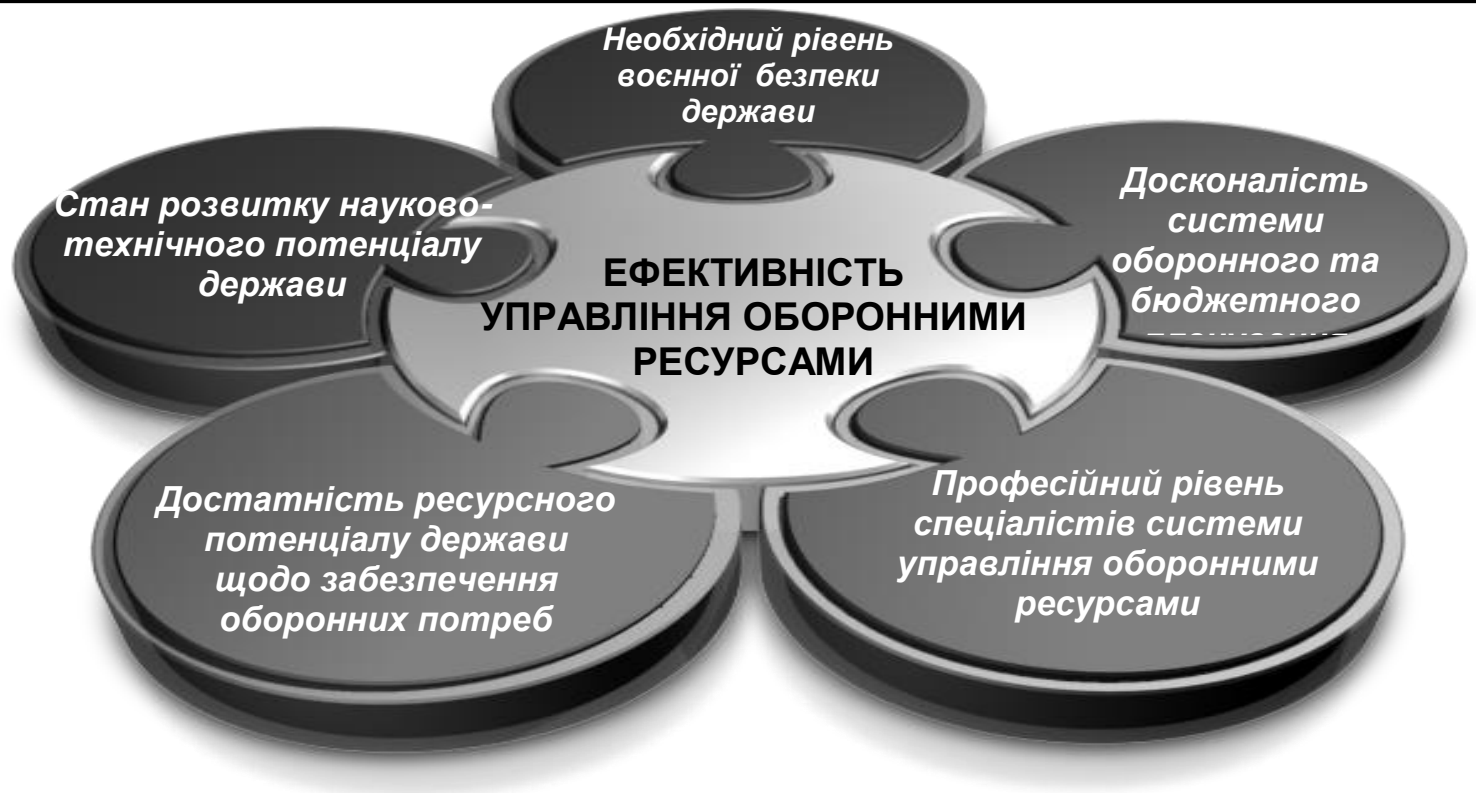

Рисунок 5 - Основні факторів, які визначальним чином впливають на ефективність управління оборонними ресурсами на рівні ЗС України

необхідний рівень воєнної безпеки держави;

досконалість системи оборонного та бюджетного планування;

достатність ресурсного потенціалу держави щодо забезпечення оборонних потреб на визначений плановий період;

стан розвитку науково-технічного потенціалу держави;

професійний рівень спеціалістів системи управління оборонними ресурсами на різних рівнях ЗС України тощо.

Управління оборонними ресурсами $\epsilon$ пошуком раціональних воєнно-економічних рішень щодо розвитку силових структур країни, які виконують завдання щодо оборони держави. В основу управління оборонними ресурсами покладено рішення значної кількості економічних задач, в яких важко говорити про абсолютно точне оптимальне рішення, оскільки його точність суттєво залежить як від методу пошуку, так і від якості вхідних даних. Більш якісне рішення вимагає більше часу та більш високої кваліфікації персоналу. Причому в останньому випадку мова йде не тільки про персонал додаткових розрахункових груп, а в першу чергу, про кваліфікацію фахівців нижчого та середнього рівнів у відповідних фінансово-економічних структурах. Вибір якості оптимального рішення залежить від доступних часових, людських та інших ресурсів i $\epsilon$ цілком прерогативою вищого керівництва. Тому загальну структуру та зміст методології управління оборонними ресурсами на різних рівнях управління 3С України можна представити як на рис. 6.

Методологія $\epsilon$ вченням про методи діяльності як такі, у нашому випадку методи діяльності системи управління ресурсами. Методологія включає в себе принципи, методи діяльності і знання, що відображує їх і являє собою сукупність прийомів дослідження, що застосовуються як в науці так і на практиці.

До основних методів діяльності на першому та другому рівні управління оборонними ресурсами у ЗС України (рівень МО України та ГШ ЗС України), можна віднести:

оперативний, системний і структурний аналізи;

планування і програмування;

створення альтернатив та моделювання процесів;

оцінювання результатів та ризиків; 


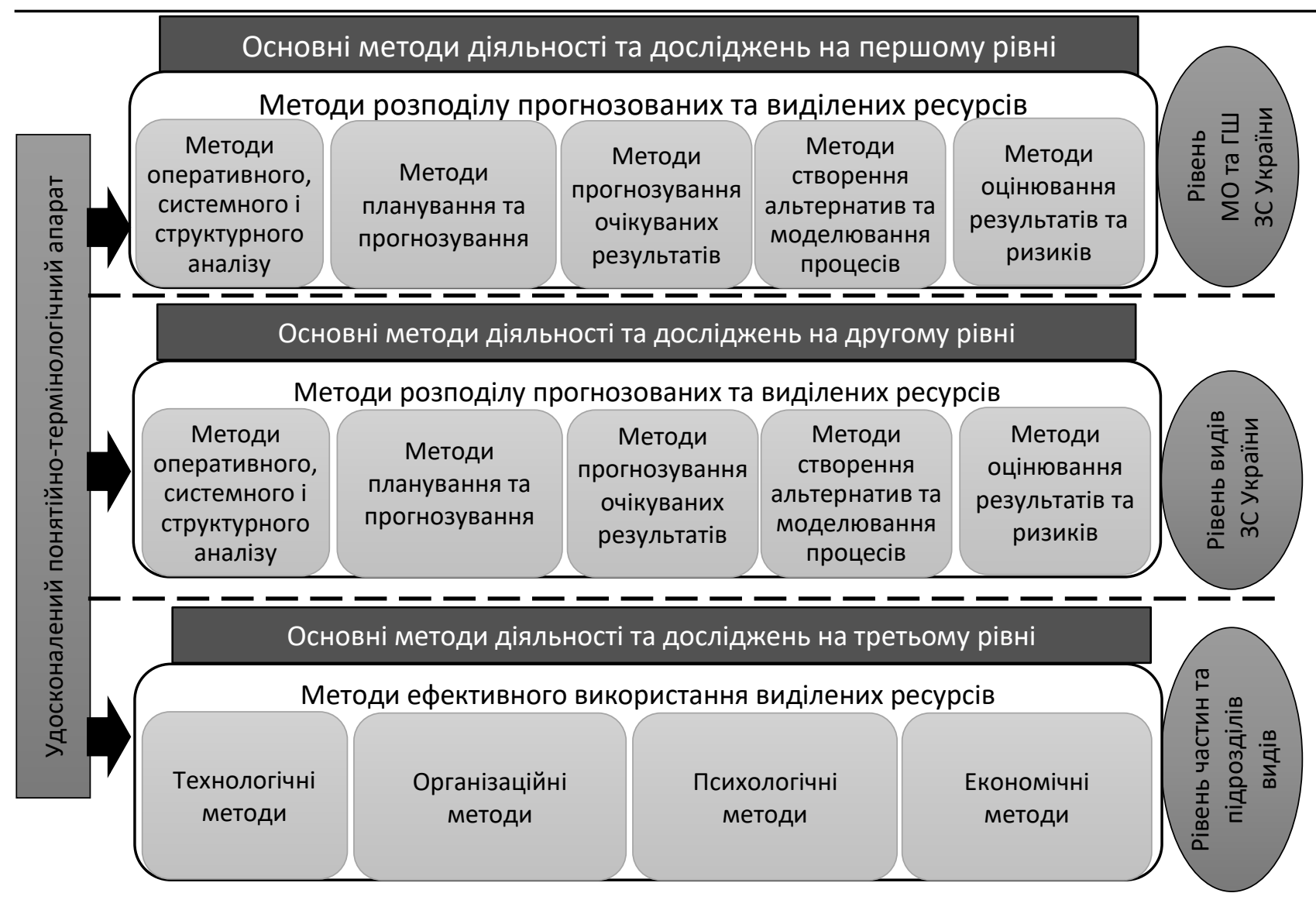

Рисунок 6 - Загальна структура та зміст методології управління оборонними ресурсами на різних рівнях управління ЗС України

інші методи і прийоми, що застосовуються до різних аспектів формування та виконання програм та планів розвитку ЗС України.

Але треба розуміти, що більшість цих методів $\epsilon$ основою для ефективного застосування методів розподілу або перерозподілу прогнозованих або вже виділених державою ресурсів на оборону.

До основних методів діяльності на рівні частин та підрозділів ЗС України можна віднести:

Технологічні методи. Щодо впровадження конкретних заходів впровадження новітніх технологічних методів.

Організаційні методи. Розробка комплексних заходів ефективного використання ресурсів різних видів для досягнення головної мети.

Психологічні методи. При виконанні управлінських, планових та організаційних рішень, а також під час використання різних видів ресурсів необхідно врахувати індивідуально-психологічні особливості і якості кожного. Фізіологічні методи. Створення необхідних умов щодо охорони та зміцнення здоров'я кожного працівника.

Економічні методи. Обґрунтування і вибір способів раціонального витрачання виділених державою ресурсів.

На основі результатів аналізу існуючого досвіду та інформації про доступні ресурси, керівництво системи управління оборонними ресурсами на перших та других рівнях постійно повинно приймати рішення щодо шляху, яким буде виконуватись пошук оптимального рішення щодо розподілу ресурсів (рис. 6).

Застосування принципів програмноцільового підходу в системі оборонного планування під час формування програм та планів розвитку ЗС України вимагає відповідного орієнтування на економічні 
можливості держави 3 метою уникнення зайвого напруження їі економіки. Оскільки розвиток спроможностей 3 С України відбувається в умовах обмежених ресурсів, то наявні підходи до вирішення питання розподілу оборонних ресурсів умовно можна поділити на декілька великих груп, які базуються на використанні методу аналогій, методів використання спрощених математичних моделей та методів теорії дослідження операцій тощо. Характеристики підходів до розподілу оборонних ресурсів під час управління ними схематично представлено на рис. 7.

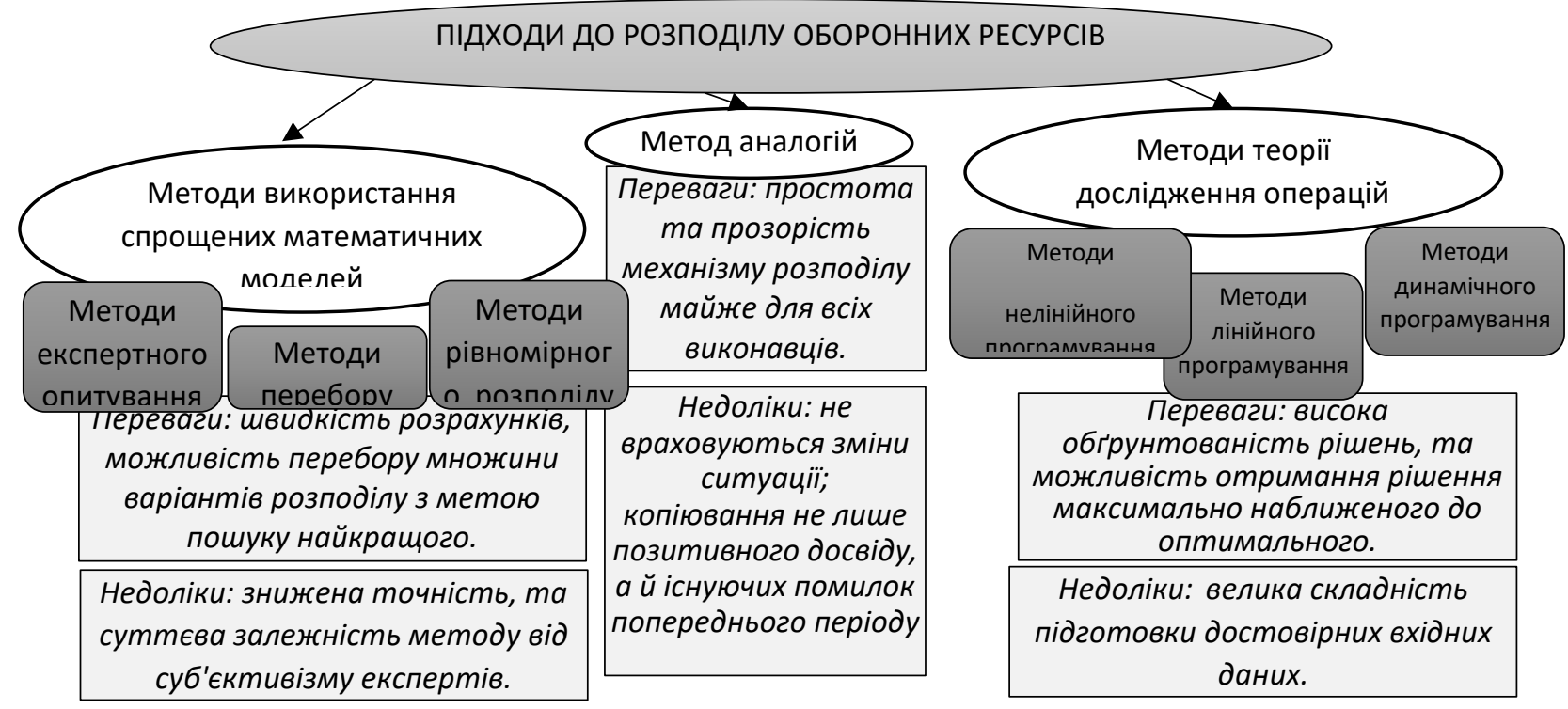

Рисунок 7 -Характеристики підходів до розподілу оборонних ресурсів під час управління ними

Найбільш традиційним та найменш трудомістким методом вважається метод аналогій, тобто розподіл за прикладом минулого періоду, за прикладом аналогічної організаційної структури ЗС або аналогічного змісту програми плану тощо.

Перевага методу: Простота та прозорість механізму розподілу майже для всіх виконавців. Недоліки: методом аналогій не враховуються зміни ситуації та виконується сліпе копіювання не лише позитивного досвіду, а й існуючих помилок та забобонів.

Розподіл оборонних ресурсів на підставі всебічно обґрунтованих математичних методів та на підставі теорії дослідження операцій, теорії оптимального управління ними - $€$ достатньо обґрунтованим та виваженим, що підвищує достовірність на стабільність прийнятих рішень, а також ефективність виконання програм та планів розвитку ЗС України.

Перевага цих методів: Висока обґрунтованість рішень та можливість отримання рішення максимально наближеного до оптимального.

Недоліки. Велика складність підготовки достовірних вхідних даних, бо деякі дані відсутні в традиційній звітності, або дуже важко формалізуються. Як наслідок - високі працевитрати та витрати календарного часу.

Методи спрощених математичних методик та моделей розподілу ресурсів представляють собою поєднання методів, що застосовують: експертні оцінки для об'єктів, які важко математично формалізувати; спрощені математичні процедури для оцінки ефективності знайдених рішень; спрощені математичні процедури для пошуку “вузьких та слабких місць” в процесі оптимізації, що дає змогу уникнути глобальних помилок та знайти субоптимальне рішення, наближене до оптимального.

Перевага. Швидкість розрахунків, можливість перебору множини варіантів 
розподілу з метою пошуку найкращого.

Недоліки. Знижена точність, та суттєва залежність методу від суб'єктивізму експертів.

Вирішення проблеми розподілу ресурсів можливе компромісними шляхами:

1. Застосування комбінованого підходу, в якому складний математичний апарат застосовується лише для програм, за якими можливо отримати вхідні дані для розрахунків відносно помірними зусиллями.

2. Застосування спрощених математичних методик, які з одного боку, в деякій мірі загрублюють рішення, але, з іншого боку, $\epsilon$ досить оперативними завдяки простоті підготовки вхідних даних.

На підставі наявної інформації керівник

\section{Висновки}

Ефективне управління ресурсами $\epsilon$ та завжди буде пріоритетним завданням будьякої системи, яка споживає ресурси, особливо якщо ця система державного значення. Для України питання оборонного менеджменту, оборонного планування на принципах програмно цільового управління та управління оборонними ресурсами $\epsilon$ достатньо новим та не вивченим, тому створення окремої ланки управління, яка першого та другого рівня управління оборонними ресурсами сам обирає метод пошуку рішення розподілу ресурсів, який забезпечить максимальну якість рішення в рамках доступних ресурсів та обстановки, що складається на час прийняття рішення.

Підходи до оптимізації розподілу ресурсів повинні бути спрямовані на досягнення максимально високих значень таких показників як економія по усіх видах ресурсів, що витрачаються, а також показників економічної ефективності, яка характеризується відношенням вартості одиниці фактичного отриманого ефекту реалізації заходів програм та планів, до вартості одиниці запланованого ефекту цих заходів.

відповідає безпосередньо за управління оборонними ресурсами ії подальший розвиток та становлення повинно бути науково-обгрунтованим та виваженим.

Подальші дослідження можуть бути пов'язані 3 розробленням практичних рекомендацій щодо створення та розвитку в ЗС України окремої ланки управління, яка відповідає безпосередньо за управління оборонними ресурсами.

\section{Список використаних джерел}

1. Малахов, В. С. Мировое военное производство и основные расходы на его содержание в контексте глобального финансового кризиса. Научный журнал КубГАУ. 2012. №84(10). - URL : http://ej.kubagro.ru/2012/10/pdf/70.pdf

2. SIPRI Yearbook 2020: Armaments, Disarmament and International Security Summary // Stockholm International Peace Research Institute. 2020. URL : http://www.sipri.org/earbook/2013/files/SIPR IYB13Summary.pdf

3. Ben Moores, The IHS Balance of Trade 2014 The Changing Worldwide Defence Market. Focus on: Eastern Europe, Middle East \& SubSaharan Africa [Electronik resourse] / Ben Moores, Georgios Salapasidis, Paul Burton //
IHS Aerospace, Defence \& Security. 2014. URL: http://www.ihs.com/balanceoftrade

4. Craig Caffrey, Defence Budgets: a Global Recalibration / Craig Caffrey, Guy Eastman, Fenella McGerty // Senior Analysts Jane's Defence Budgets, IHS Aerospace, Defence and Security. - Washington, D.C. and London, UK: 13 February 2014. $42 p$.

5 Радвик Б. Военное планирование и анализ систем / Перевод с англ. В. Базарова / Под ред. А. М. Пархоменко Москва: Воениздат, 1972. 477 c.

6. Хомчак Р. Б., Семененко О. М., Бокій В. Г., Трегубенко С. С., Москаленко І. В. Аналіз та оцінка воєнно-економічних умов розвитку збройних сил країн світу та України. 3б. наук. пр. ЦНДІ ЗС України. Київ: 2019. № 5 (91). 
C. 91-109.

7. Харламова Г. Оцінка стабільності національної безпеки: нові рамки для аналізу. URL: http://ukraine2030.org/uk/ blog/view/175-Ocinka-stabilnosti-

nacionalnoyi-bezpeki-novi-ramki-dlja-analizu

8. Бэтлер А. Национальные интересы, национальная и международная безопасность. полИС. 2002. № 4. С. 146158.

9. Горбулін В. П. Стратегічне планування: вирішення проблем національної безпеки. Монографія / В. П. Горбулін, А. Б. Качинський. К. : НІСД, 2010. - 288 с.

10. Общая теория национальной безопасности: Учебник / Под ред. А. А. Прохожева. М.: РАГС, 2005. - $344 \mathrm{c}$.

11. Ткаченко В. І., Смірнов Є. Б., Астахов О. О.
Шляхи формування системи забезпечення національної безпеки. URL: www.hups.mil.gov.uararticleszhups_2015_2_3 12. Шуляк П. І., Семененко О. М., Бокій В.Г., Совгіря Т. М., Пекуляк Р.О. Методичний підхід до оцінювання здатності Збройних Сил України до виконання покладених на них завдань з урахуванням ресурсних можливостей держави. 3б. наук. пр. ЦНДІ ЗС України. Київ. 2020. № 1 (92).

13. Україна. Офіційний сайт Державної служби статистики України. - URL: www.ukrstat.gov.ua.

14. Україна. Офіційний сайт Міністерства фінансів України. - URL: www.minfin.com.ua.

15. Щорічник СИПРИ 2019: озброєння, роззброювання й міжнародна безпека. Москва. Наука, 2019.

\title{
Методологические основы управления оборонными ресурсами в Вооруженных силах Украины
}

\author{
Олег Семененко* 1 А; Петр Онофрийчук 2 А; Ирина Чернышева ${ }^{3 \text { A; }}$ \\ Олег Остапец ${ }^{4 \text { B }}$, Иван Мотрунич ${ }^{5 \text { B }}$; Ольга Романченко ${ }^{6 \mathrm{C}}$ \\ * Corresponding author: ${ }^{1}$ доктор военных наук, старший научный сотрудник, начальник отдела, e-mail: aosemenenko@ukr.net, ORCID: 0000-0001- \\ 6477-3414 \\ 2 кандидат экономических наук, професор, e-mail: aosemenenko@ukr.net, ORCID: 0000-0003-2203-5282 \\ 3 кандидат военных наук, старший научный сотрудник, e-mail: aosemenenko@ukr.net, ORCID: 0000-0002-5958-7059 \\ ${ }^{4}$ кандидат военных наук, e-mail: aosemenenko@ukr.net, ORCID: 0000-0002-4702-980X \\ ${ }^{5}$ соискатель, e-mail: aosemenenko@ukr.net, ORCID: 0000-0001-6117-1784 \\ ${ }^{6}$ соискатель, e-mail: alena.rondo@gmail.com, ORCID: 0000-0003-1640-853X \\ А Центральный научно-исследовательский институт Вооруженных Сил Украины, г. Киев, Украина \\ в Генеральный штаб Вооруженных сил Украины, Киев, Украина \\ с Национальный университет обороны Украины имени Ивана Черняховского, Киев, Украина
}

\section{Аннотация}

В существующих условиях развития государства, когда системы оборонного планирования Украины адаптируется к стандартам НАТО, развитие Вооруженных Сил (ВС) Украины должно базироваться на показателях необходимого уровня обороноспособности страны с учетом ее экономических возможностей по обеспечению потребностей в оборонных ресурсах. Для Украины вопрос оборонного менеджмента, оборонного планирования основанный на принципах программно-целевого управления и управления оборонными ресурсами недостаточно изучен. Руководство ВС Украины и государства в целом желает быстро перейти к оборонному планированию по стандартам НАТО, а именно с применением метода “планирование на основе возможностей”. Однако сейчас в Украине отсутствуют методологические основы управления оборонными ресурсами, что негативно влияет на развитие ВС. Анализ современных исследований показывает, что сегодня активно используется термин "управления оборонными ресурсами” однако, в литературе встречается множество его неоднозначных толкований. Кроме того, трудно найти единый подход к управлению оборонными ресурсам. Поэтому необходимой и актуальной задачей является дать определение термину “управление ресурсами" и определить 
методологические основы управления оборонными ресурсами В ВС Украины. Предложенные методологические основы должны дать ответы на вопросы о перечне, содержании и алгоритме реализации методов управления оборонными ресурсами, а также раскрыть вопросы практической значимости процесса управления оборонными ресурсами. Предлагаемые методологические основы управления оборонными ресурсами по своей сути является совокупность уточненного (стандартного для всех уровней ВС Украины) понятийно-терминологического аппарата, разработанной концепции дальнейшего развития системы управления оборонными ресурсами и методического аппарата военно-экономического обоснования развития ВС Украины, который представляет собой набор методов, приемов, способов исследования вопросов управления оборонными ресурсами.

Дальнейшие исследования могут быть связаны с разработкой практических рекомендаций по созданию и развитию в ВС Украины отдельного звена управления, которое отвечает непосредственно за управление оборонными ресурсами.

Ключевые слова: ресурсы, обеспечение, расходы, менеджмент, эффективность.

\title{
Methodological fundamentals of defense resources management in the armed forces of Ukraine
}

\author{
Oleh Semenenko * 1 A; Petro Onofriichuk 2 A; Iryna Chernyshova ${ }^{3}$ A; \\ Oleh Ostapets $^{4 \mathrm{~B}}$; Ivan Motrunych ${ }^{5 \mathrm{~B}}$; Olha Romanchenko ${ }^{6 \mathrm{C}}$ \\ * Corresponding author: ${ }^{1}$ Doctor of Military Sciences, Professor, Head of Department, e-mail: aosemenenko@ukr.net, ORCID: 0000-0001-6477-3414 \\ ${ }^{2}$ Candidate of Economic Sciences, Senior Researcher, e-mail: aosemenenko@ukr.net, ORCID: 0000-0003-2203-5282 \\ ${ }^{3}$ Candidate of Economic Sciences, Senior Researcher, e-mail: aosemenenko@ukr.net, ORCID: 0000-0002-5958-7059 \\ ${ }^{4}$ Candidate of Military Sciences, e-mail: aosemenenko@ukr.net, ORCID: 0000-0002-4702-980X \\ ${ }^{5}$ PhD student, e-mail: aosemenenko@ukr.net, ORCID: 0000-0001-6117-1784 \\ ${ }^{6} \mathrm{PhD}$ student, e-mail: alena.rondo@gmail.com, ORCID: 0000-0003-1640-853X \\ ${ }^{A}$ Central Research Institute of the Armed Forces of Ukraine, Kyiv, Ukraine \\ ${ }^{B}$ General Staff of the Armed Forces of Ukraine, Kyiv, Ukraine \\ ${ }^{c}$ National University of Defense of Ukraine named after Ivan Chernyiakhovskyi, Kyiv, Ukraine
}

\begin{abstract}
In the current conditions of state development, when Ukraine's defense planning system adapts to NATO standards, the development of the Armed Forces (AF) of Ukraine should be based on indicators of the required level of defense capabilities of the country, taking into account its economic capabilities to meet defense resources. For Ukraine, the issues of defense management, defense planning based on the principles of program-targeted management and defense resources management are insufficiently studied. The leadership of the Armed Forces of Ukraine and the state as a whole wants to move to defense planning according to NATO standards as soon as possible, namely using the "capability-based planning" method. However, today in Ukraine there is no methodological basis for the management of defense resources, which has negative consequences. Analysis of modern research shows that today the term management of defense resources is actively used, however, in the literature there are many ambiguous interpretations. In addition, it is difficult to find a unified approach to defense resource management. Therefore, it is necessary and urgent to define the term "resource management" and to outline the methodological basis for the management of defense resources in the Armed Forces of Ukraine. The formed methodological bases should give answers to the questions concerning the list, the maintenance and algorithm of realization of methods of management of defense resources, and also to open questions of practical significance of process of management of defense resources. The proposed methodological bases of defense resources management are essentially a set of refined (standard for all levels of the Armed Forces of Ukraine) conceptual and terminological apparatus, developed concept
\end{abstract}


of further development of the defense resources management system and methodological apparatus of military-economic substantiation of the Armed Forces of Ukraine, which is a set of methods. receptions, ways of research of questions of management of defense resources.

Further research may be related to the development of practical recommendations for the creation and development of a separate branch of government in the Armed Forces of Ukraine, which is directly responsible for the management of defense resources.

Keywords: resources, provision, costs, management, efficiency.

\section{References}

1. Military Doctrine of Ukraine (as amended in 2004): Decree of the President of Ukraine of June 15, 2004 № 648/2004 // Official Gazette of Ukraine. 2004. № 30. [in Ukrainian]

2. Military security and defense of Ukraine. Explanatory dictionary of normative-legal and scientific terms and definitions. Ed. F.V. Saganyuk. National Research Center for Defense Technologies and Military Security of Ukraine. Kyiv: 2007. [in Ukrainian]

3. On National Security of Ukraine. Verkhovna Rada of Ukraine. Verkhovna Rada: Law of Ukraine № 2469-VIII. [in Ukrainian]

4. On the National Security Strategy of Ukraine: Decree of the President of Ukraine №392 / 2020. On the decision of the National Security and Defense Council of Ukraine of September 14, 2020. Available from: https://www.president.gov.ua/documents/3 922020-35037. [in Ukrainian]

5. Radvik B. Military planning and systems analysis / Translated from English. V. Bazarova / Ed. A.M. Parkhomenko. Moscow: Voenizdat, 1972. 477 p. [in Russian]

6. Khomchak R.B., Semenenko O.M., Bokiy V.G., Tregubenko S. S., Moskalenko I. V. (2019). Analysis and assessment of military and economic conditions for the development of the armed forces of the world and Ukraine. Collection of scientific works of the Central Research Institute of the Armed Forces of Ukraine. Kyiv: № 5 (91). pp. 91-109. [in Ukrainian]

7. Kharlamova G. Assessing the stability of national security: a new framework for analysis. Available from: http://ukraine2030.org/en/blog/view/175Ocinka-stabilnosti-nacionalnoyi-bezpekinovi-ramki-dlja-analizu. [in Ukrainian]

8. Butler A. (2002). National interests, national and international security. POLICE. № 4. P. 146-158.

9. Gorbulin V. P. Strategic planning: solving national security problems. Monograph / V.P. Gorbulin, A. B. Kaczynski. Kyiv, 2010. 288 s. [in Ukrainian]

10. General theory of national security: Textbook / Ed. A. A. Prohogeva. Moscow.: RAGS, 2005. 344 s. [in Russian]

11. Tkachenko V. I., Smirnov E.B., Astakhov O.O. Ways of forming a system of national security. Available from: www.hups.mil.gov.uararticleszhups_2015_2 _3 [in Ukrainian]

12. Shulyak P. I., Semenenko O. M., Bokiy V. G., Sovgirya T. M., Pekulyak R. O. (2020). Methodical approach to assessing the ability of the Armed Forces of Ukraine to perform the tasks assigned to them, taking into account the resource capabilities of the state. Collection of scientific works of the Central Research Institute of the Armed Forces of Ukraine. Kyiv. № 1 (92). [in Ukrainian]

13. Ukraine. Official site of the State Statistics Service of Ukraine: URL: www.ukrstat.gov.ua. [in Ukrainian]

14. Ukraine. Official site of the Ministry of Finance of Ukraine. Available from: www.minfin.com.ua. [in Ukrainian]

15. SIPRI Yearbook 2019: armaments, disarmament and international security. Moscow. Science, 2019. [in Russian] 